\title{
Factors influencing the adoption of improved cultivars: a case of peach farmers in Pakistan
}

\author{
Arif Ullah ${ }^{1} \odot$ Dilawar Khan ${ }^{2}$ Shaofeng Zheng $^{{ }^{*}}$ () Uzair Ali ${ }^{1}$ \\ ${ }^{1}$ College of Economics and Management, Northwest A\&F University, 3 Taicheng Road, 712100, Yangling, Shaanxi, China. E-mail: zsfeng@nwsuaf.edu.cn. \\ ${ }^{*}$ Corresponding author. \\ ${ }^{2}$ Department of Economics, Kohat University of Science \& Technology, 26000, Kohat, Pakistan.
}

ABSTRACT: This study aimed to investigate factors influencing the adoption of improved cultivars (ICs) in peach production in Khyber Pakhtunkhwa province of Pakistan. A total of 270 respondents were randomly selected from the three different cultivated areas of Khyber Pakhtunkhwa, namely, Peshawar, Nowshera and Swat. Binary choice model was used in this study to categorise the ICs of peach farmers into adoption and non-adoption. The study identifies that socio-economic, institutional farm resources, and climatic factors are influencing the adoption of ICs of peach production. Results of the estimated model reveal that farmer's age, education, household size, membership, cell phone, farm size, extension services and the role of the non-government organization have a positive effect on adoption of ICs. In addition, farmer's experience, off-farm income, livestock and machinery ownership, credit access and inputs prices have a positive and significant impact on ICs adoption. Moreover, results of the logit model demonstrate that climatic related factors have a highly significant and positive impact on the adoption of ICs. These results suggested that institutional services should be strengthened to provide managerial and technical skills on ICs technology adoption and on time provision of financial services to enhance the productivity of peach farmers.

Key words: improved cultivars, peach, technology, agriculture.

Fatores que influenciam a adoção de cultivares melhoradas: um caso de produtores de pêssego no Paquistão

RESUMO: Este estudo tem como objetivo investigar os fatores que influenciam a adoção de cultivares melhoradas (ICs) na produção de pessegueiros na província de Khyber Pakhtunkhwa, no Paquistão. Um total de 270 entrevistados foram selecionados aleatoriamente a partir das três diferentes áreas cultivadas de Khyber Pakhtunkhwa, Peshawar, Nowshera e Swat. O modelo de escolha binária foi usado neste estudo para categorizar os ICs dos produtores de pêssego em adoção e não-adoção. O estudo identifica que fatores socioeconômicos, institucionais, recursos agrícolas e climáticos influenciam a adoção de ICs de produção de pêssego. Os resultados do modelo estimado revelam que a idade do agricultor, educação, tamanho do agregado familiar, adesão, telefone celular, tamanho da fazenda, serviços de extensão e o papel da organização não-governamental têm efeito positivo sobre a adoção de ICs. Além disso, a experiência do agricultor, a renda fora da propriedade, a posse de gado e maquinaria, acesso ao crédito e preços dos insumos têm um impacto positivo e significativo na adoção dos ICs. Os resultados do modelo logit demonstram que os fatores climáticos relacionados têm um impacto altamente significativo e positivo na adoção de ICs. Estes resultados sugerem que os serviços institucionais devem ser fortalecidos para prover habilidades gerenciais e técnicas na adoção de tecnologia de ICs e no fornecimento de serviços financeiros para aumentar a produtividade dos produtores de pêssego.

Palavras-chave: cultivares melhorados, pêssego, tecnologia, agricultura.

\section{INTRODUCTION}

The role of agricultural sector in Pakistan's economic development cannot be denied. Over an extended period, this sector is considered as the key component of Pakistan economy and accounts for $19.5 \%$ of the Gross Domestic Product (GDP), employing $42.3 \%$ of the labour force of the country (GOP, 2017). Recently, Pakistan agricultural sector is suffering from various problems such as lack of technology, improper availability of inputs, severe drought, degradation of environmental and changes in climate. Climate change has already affected millions of people and continuously increasing the risk of hunger and food insecurity (GOP, 2015a). More specifically, those countries whose economies are highly dependent on agriculture, fisheries, and forestry which are primarily climate-sensitive sectors (WORLD BANK, 2009; TAMBO \& ABDOULAYE, 2012). It is estimated that this issue may severely affect global food security by the middle of the $21^{\text {st }}$ century. It is also projected that South Asia is more vulnerable to food insecurity (ABID et al., 2015). Pakistan is vulnerable to climate change according to the latest report of World Bank (AHMED \& SCHMITZ, 2011). Based on global climate risk index, Pakistan has been ranked $12^{\text {th }}$ in term of vulnerability to climate over the period of 1993 to 2012 (ABID et al., 2015). 
Conversely, it is projected that Pakistan crop productivity has been substantially reduced due to the incidence of pest's attack and prevalence of diseases. Pakistan is already a water-stressed country and is on its way to becoming water scarce (KHAN et al., 2011). Therefore, modern adaptation is a necessity against these aforementioned problems. A key component of adaptation is agricultural technology to enhance crop productivity (SMITH, 2014). The other most confronting issue is the per hectare low productivity of fruits orchard in Pakistan, compared to other nations of the world (BAKHSH et al., 2006). However, for the minimization of post-harvesting losses, the use of proper infrastructure facilities and technologies are essential. Technology can help to protect society from changing climate conditions, improve the productivity of the crop, and help in the most efficient use of threatened resources (SMITH, 2014). Technology change has been widely acknowledged as a critical component of agricultural development and economic growth especially in countries with agrobased economies (DIAO et al., 2010). Agricultural technologies are considered the primary sources of increasing crop production. Increasing crop production means improving the household food security and subsequently raising the income of the farmers. Moreover, agricultural innovation involves the continuous use of new and existing knowledge emanating from diverse sources within and outside research domains to improve food production and household welfare (MUTENJE et al., 2016).

For crop production technology ICs are considered the most significant factor. Enhancement of crop productivity in the past is mainly due to an elevation of input factor; however, once these have been maximized, as under prevailing practices of agriculture, further maximization from inputs of agriculture seems uncertain (MARTIN et al., 2005). Therefore, future crop productivity is highly dependent on the adoption of new and ICs (TOKATLIDIS, 2017). Consequently, it is essential to quantify factors influencing the ICs adoption of peach farmers. This study would undoubtedly help to increase peach crop productivity making policy design in agriculture for technology adoption.

Various factors determine the adoption of different agricultural innovations and technologies. Many empirical studies focus on farm size as the first and probably the most important factors (ABDULAI \& HUFFMAN, 2014; MARTEY et al., 2014). The reason is farm size can affect and in turn be affected by the other factors influencing adoption. Age is an essential factor that influences the probability of adoption of new technologies because it is said to be a primary latent characteristic in adoption decisions (EMMANUEL et al., 2016; MARTEY et al., 2014) while Abdoulaye \&Sanders (2005) consider education as essential factor for agricultural technology adoption. A number of studies established the effect of credit on adoption, having a positive influence on agricultural technology (MARTEY et al., 2014; ABDULAI \& HUFFMAN, 2014; ABDULAI et al., 2011). Furthermore, many researchers (ABDOULAYE \& SANDERS, 2005; ABDULAI et al., 2011; MARIANO et al., 2012; ABDULAI \& HUFFMAN, 2014) have mentioned various factors such as, age, education, gender, farm size and location (socio-economic factors) and extension contact, leasehold, credit access and market (institutional factors) significantly contributes to adoption of agricultural technologies.

A wide range of tropical, sub-tropical and temperate fruits are grown in Pakistan (UNIDO, 2010). Peach is the second most important stone fruit in Pakistan. It belongs to the family Rosaceae. It is the most important, among the stone fruit and is temperate. It is a remarkable fruit having different attributes; i.e., sweetness, juiciness, fleshiness, attractive in flavor and aroma. Due to these attributes, it is very delicious (YU et al., 2015). Despite its various importance, the cultivation of this crop is decreasing in the recent past decades (GOP, 2015b). This crop has the potential to fulfill the demand of the home market for domestic consumption (HABIB, 2015). Therefore, to increase the peach production in the country, an appropriate ICs technology adoption is essential.

The main objective of this paper is to assess determinants of ICs technology adoption in peach production in Khyber Pakhtunkhwa province of Pakistan. In Pakistan, especially in Khyber Pakhtunkhwa province, different ICs are used because of their variety of functions and their requirements such as soil type, climatic conditions, growth standards and disease susceptibility. Commercially used rootstock for peach propagation includes the following ICs: Lovell, Nemagaurd, Hall fold, Wild peach, Peshawar local, Swat local (SHAH et al., 2013). However, the most prominent ICs are Early Grand, Spring Crest, Carmen, Elberta, Sohani, Maria Delezia, Florida King 6-A, 8-A, Tex A6-69, Tex Y455, Khyber 2, Gul Rukh, and NJ-238.

\section{MATERIALS AND METHODS}

Selection of the study area

This study was conducted in Khyber Pakhtunkhwa province of Pakistan. The total length 
of the province is 408 miles between the parallels and the total width between the meridians is 279 miles. Geotropically, it is located between $31^{\circ} 15^{\prime}$ and $36^{\circ}$ $57^{\prime}$ 'North latitude and $69^{\circ} 5^{\prime}$ ' and $74^{\circ} 7^{\prime}$ 'East longitude (KHAN, 2012). The total province area is 10.17 million hectares which as $12.8 \%$ of the total area of the country and situated at the junction of Himalaya, Karakorum, and Hindukush mountain ranges (KHAN, 2012). Figure 1 shows the selected study districts in Khyber Pakhtunkhwa, Pakistan. It is important to note that the peach crop and study area selection in this research was due to two main factors. Firstly, as mentioned before in introduction section that Khyber Pakhtunkhwa province is blessed with a wide range of fruits and is the largest producer of delicious fruits in Pakistan; secondly, peach is the leading fruit crop among the fruit crops/orchards of all categories in this province.

\section{Sampling technique and data samples}

The data was collected using a multistage sampling design. In the first stage, the northern region of Khyber Pakhtunkhwa province (traditional peach producing belt) was selected. In the second stage, three districts namely Peshawar, Nowshera, and Swat were selected purposely according to their relative importance in fruit production. In the third stage, main towns and union councils were selected from purposively-selected districts. Finally, a total number of 21 villages were selected based on more peach fruit plants, a large number of practicing peach growers and orchard owners in these villages. Direct elicitation method was employed for data collection to ask the ICs technology adoption status of peach farm households. The interviewer applied a structured and comprehensive questionnaire. The data collection was carried out from 270 respondents using proportional sampling allocation technique.

\section{Estimation of binary choice logit models}

The use of dichotomous choice data model is the most common method to investigate whether technology is adopted or not adopted. Binary logistic regression is typically used when the dependent variable is dichotomous, and the independent variables are either continuous or categorical variable. Therefore, this study uses a binary logistic regression model. In deciding whether or not to adopt a given ICs technology, it may assume that the producer weighs up the marginal advantages and disadvantages of adoption. Moreover, it is important to know the individual factor influencing the farmer's choice. Hence, dummy variables can be used to describe the observed pattern of adoption: $\mathrm{y}_{\mathrm{i}}= \begin{cases}1 & \text { If the farmer adopts ICs } \\ 0 & \text { If the farmer does not adopt ICs }\end{cases}$

The farmer's adoption and non-adoption of ICs technology probabilities is described as $\mathrm{P}=\mathrm{P}$ $\left[\mathrm{Y}_{\mathrm{i}}=1\right]$ and, $1-\mathrm{P}=\left[\mathrm{Y}_{i}=0\right]$ respectively. The probability function of this binary adoption variable can express as $f(\mathrm{Y})=\mathrm{P}^{\mathrm{y}}\left(-\mathrm{P}^{1-\mathrm{y}}\right)$ where $\mathrm{Y}=0,1$. The econometric techniques used in this manuscript obtained from GREENE (2005) and HILL et al. (2008).

To investigate the factors influencing the adoption of ICs, this study constructs a binary choice model to specify the factors influencing farmer's decision making. Farmers often consider the benefits from adoption of new technologies such as ICs, which can be denoted by $\mathrm{U}^{*}(<)$ where $(<)$ is net farm income. If the expected utility from adoption is greater than non-adoption, the technology is considered to be adopted and can be mathematically expressed as $\mathrm{U}_{i}{ }^{*}(<)>\mathrm{U}_{N}{ }^{*}(<)$. The farmer's decision-making parameters are often un observed and can be measured by a latent variable $\mathrm{U}_{i}^{*}$ that might be due to socio-economic characteristics, institutional, farm resources and environmental factors variables $\left(x_{i}\right)$ :

$$
\mathrm{U}_{\mathrm{i}}^{*}=\mathrm{X}_{\mathrm{i}} \beta+\mathrm{e}_{\mathrm{i}} \quad \mathrm{i}=1,2, \mathrm{~K}, \mathrm{~N}
$$

Where $\beta$ denotes the adoption parameters and $e_{i}$ is a random error term. After the determination of farmer's technology choice, dummy variables can be used to express the observed pattern of ICs adoption $\left(y_{i}\right)$ while the observed values of $y_{i}$ are related to latent variable $\mathrm{y}^{*}$; that is otherwise.

$$
\begin{aligned}
& \mathrm{y}_{\mathrm{i}}=1 \quad \text { if } \mathrm{U}_{\mathrm{A}}^{*}(\pi)>\mathrm{U}_{\mathrm{N}}^{*}(\pi) \\
& \mathrm{y}_{\mathrm{i}}=0
\end{aligned}
$$
is given below:

Thus, the technology adoption probability

$$
p\left[y_{i}=1\right]=p\left(e_{i}>-X_{i} \beta\right)=1-F\left(X_{i} \beta\right)=F\left(X_{i} \beta\right)
$$

Where $\beta$ is the parameters used in the maximum likelihood procedure and $F$ is the cumulative distribution function (CDF). Binary choice models differ only in the assumption about the functional form of F. To determine the farmers' adoption probability of ICs technology; the logit model can be used and expressed as:

$$
P_{i}=P\left[y_{i}=1\right]=\frac{e^{x_{i} \beta}}{1+e^{x_{i} \beta}}
$$

After the estimation of the maximum likelihood of the logit model, the following procedure was 


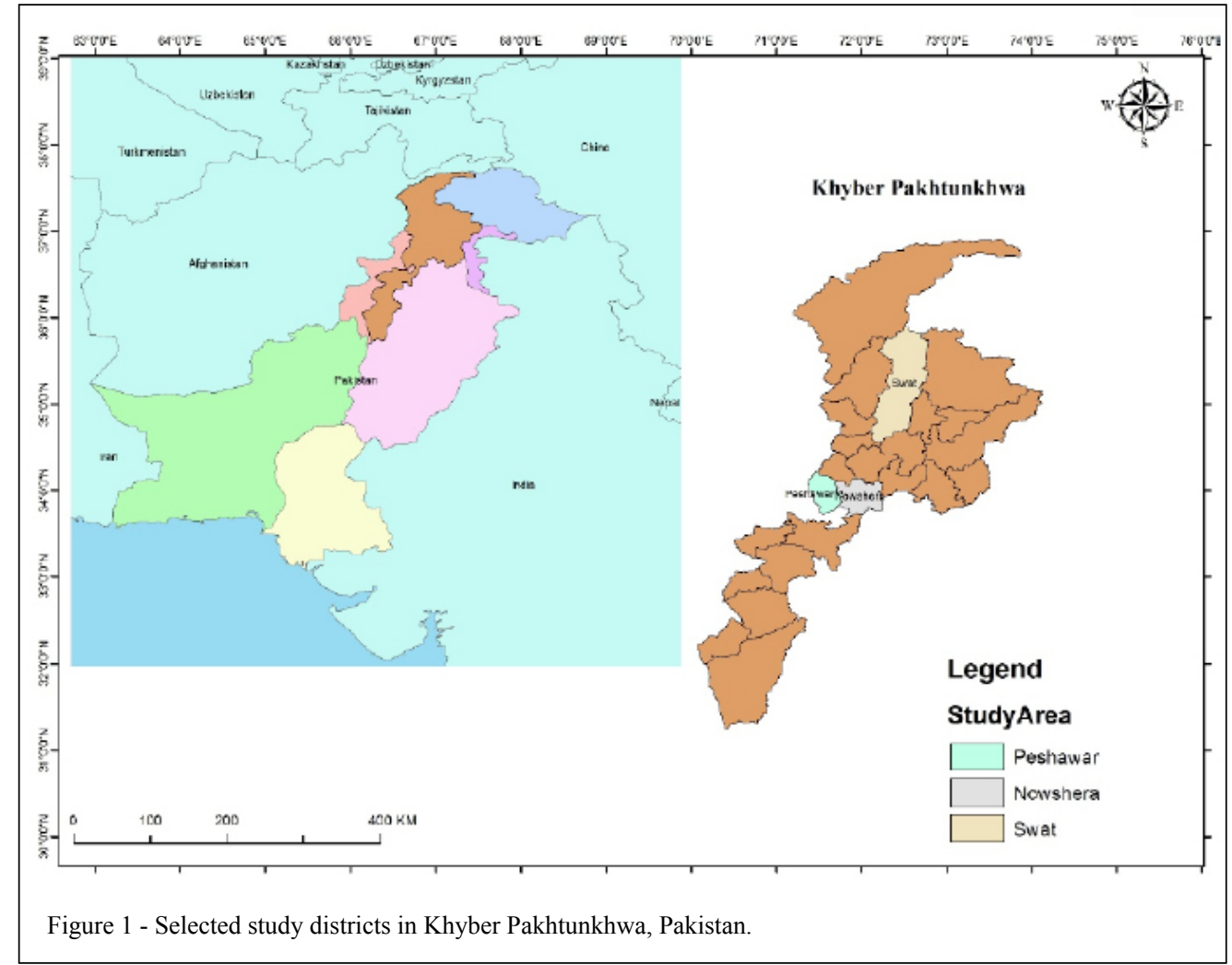

employed. Given the specific farmers characteristics $\left(x_{i}\right)$, initially, the probability of ICs adoption was predicted. Next, for a change in farmer-specific characteristics $\left(x_{i}\right)$ the change in probability $(\Delta \mathrm{P})$ was estimated. For example, if a farm size $\left(x_{1}\right)$ has $x_{a}=1$ acre and $x_{b}=2$ acres of two specific values, the change in probability $(\Delta \mathrm{P})$ as a result of the change in farm size from 1 to 2 acres is determined as under:

$\Delta P=F\left(\beta_{0}+\beta_{1} x_{b}+\beta_{2} x_{2}+\ldots+\beta_{k} x_{k}\right)-F\left(\beta_{0}+\beta_{1} x_{a}+\beta_{2} x_{2}+\ldots+\beta_{k} x_{k}\right)$

Third, if other factors being constant (cetrisperibus), the marginal effect on the probability that farmer chooses to adopt ICs can be computed as:

$\left.\frac{\Delta \mathrm{P}_{\mathrm{i}}}{\Delta \mathrm{x}_{\mathrm{i}}}\right|_{\text {all other } \mathrm{x} \text { constant }}=\frac{\partial \mathrm{P}_{\mathrm{i}}}{\partial \mathrm{x}_{\mathrm{i}}}$

Finally, calculating the odds ratio of technology adoption, which is the frequency that a farmer will use ICs rather than local cultivar (HILL et al., 2008):

$$
\frac{p_{i}}{1-p_{i}}=e^{x_{i} \beta}
$$

\section{RESULTS AND DISCUSSION}

\section{Description of the variables}

Explanatory variables included in the binary choice model were classified into four sections: socio-economic, farm resources, institutional and climatic factors (Table 1). The inclusion of the various explanatory variables and their prior expected influence in the models was based on theoretical foundations and from past research literature. For example, research studies reveal that age (MARIANO et al., 2012; EMMANUEL et al., 2016; MARTEY et al., 2014), education (ABDOULAYE \& SANDERS, 2005), farm size (ABDULAI \& HUFFMAN, 2014; MARTEY et al., 2014), credit (MARTEY et al., 2014; (ABDULAI \& HUFFMAN, 2014; ABDULAI et al., 2011) variables significantly influence the adoption of agricultural technologies. A recent study reveals that farm size had a positive relationship with the adoption of modern agricultural technology. This means that farmers with larger farm size are more likely to adopt irrigation equipment, tractors, and modern variable inputs (AKUDUGU et al., 2012). Moreover, previous research studies 
suggested socio-economic factors (age, education, gender, farm size, location) and institutional factors (extension contact, leasehold, credit access, market) are hypothesized to influence the adoption of agricultural technologies (ABDOULAYE \& SANDERS, 2005; ABDULAI et al., 2011; MARIANO et al., 2012; ABDULAI \& HUFFMAN, 2014). Furthermore, the choice of access to extension services variable have been incorporated in modeling, because it plays a vital role in the dissemination of useful and practical information related to agricultural technology adoption (NAMBIRO et al., 2006; ADEBAYO, 2012; PAN, 2014). In addition to the input variables, three variables are specified to capture the effects of climatic factors on ICs technology adoption of peach production, i.e., natural disaster risk perception, soil quality perception, and weather shocks awareness. Natural disaster risk perception was measured based on low, medium and high ranking when a farmer perceived natural event risk such as flood, drought, windstorm, disease/insect's outbreak within cropping season. The soil quality perception was measured based on low, medium and high ranking when a farmer perceived the capacity of a specific kind of soil to function within the specific natural environment. Similarly, weather shocks awareness was measured based on low, medium and high ranking when a farmer was aware of the fluctuation in the temperature and rainfall within the cropping season.

Table 2 shows the descriptive statistics of the variables for adopters and non-adopters of ICs technology. Socio-economic characteristics of farmers such as age, education, experience household size and off-farm income show slight variation across groupings. On an average, peach farmers have 5 years of schooling, 8 years of peach farming experience and 6 household members. The average age of the peach farmer was 42 years. On average, only $48.9 \%$ and $38.9 \%$ of respondents could access credit and extension services, respectively in the selected districts. More farmers who own farm resources such as land and machinery belonging to the technology adopter group, and they also have higher off-farm income. Institutional factors play a vital role in the daily operation of the peach farm. These factors are biased towards technology adopters.

To check the multicollinearity of the data diagnostic tests were carried out. Variation Inflation Factor (VIF) and Condition Indices (CI) were examined with no evidence of multicollinearity reported. Marginal effects are reported because coefficients can be difficult to interpret for the model, given the need to compare to a base outcome.
The estimates of the binary logit model contain 17 explanatory variables and provide insightful results. Table 3 presents the binary logit estimated coefficients of the parameters and the marginal effects. Results of the Wald Chi-squared test is statistically significant at $1 \%$ level, suggesting that the explanatory variables jointly determine the adoption of ICs among peach producers. According to Hensher and Johnson (1981) consider pseudo-R ${ }^{2}$ value between the range of 0.20 and 0.40 to be a good fit. In this study, the goodness-of-fit measures at the bottom of Table 3, the pseudo- $\mathrm{R}^{2}$ statistics suggested our models fit the data reasonably well. Moreover, pseudo- $\mathrm{R}^{2}$ value 40 percent present interesting results. This gives a meaning that variance in adoption is explained by socio-economic, farm resource, institutional and climatic factors are 40 percent. The remaining 60 percent variance may be due to ICs innovation attributes.

The effect of socio-economic characteristics of the farmers is expected to encourage the adoption of ICs. Results revealed that the coefficient of farmer's experience had a positive and significant effect on adoption of ICs. In accordance with our expectations, farmers who are more experienced have greater ability to process information and search for technologies suitable to their production constraints than those who are less experienced. The marginal effects indicate that each additional year increase in experience of the farmer increases the probability of adopting the periphery technique by $0.8 \%$. Our results are in line with ABDULAI et al. (2011), who reported that farmer experience plays a significant role in the adoption of agricultural technologies and innovations. To measure the impact of the availability of more financial resources of the farmer to adopt new technology, off-farm income variable was used. The coefficient of off-farm income had a significant and positive relationship with the adoption of ICs. The estimated marginal effect of this variable was also found very high; i.e. 9.1\%. Off-farm income generated from off-farm activities. For instance, employment, small business enterprises, and raising livestock. In general, alternative income resources can help farmers to make necessary and timely investments, such as optimal inputs allocation and utilization (OSENI \&WINTERS, 2009; CHAVAS et al., 2016). The coefficient of farmer's age had a positive relationship with the adoption of technology, and the estimated marginal effect indicates that the probability of adopting the technology increases by $0.3 \%$. These results of the study are consistent with the results of 
Table 1 - Description of the variables in the technology adoption model.

\begin{tabular}{|c|c|c|}
\hline Variables & Description & Expected Sign \\
\hline \multicolumn{3}{|c|}{--------------------------------------------------------Socioeconomic characteristics---------------------------------------------- } \\
\hline Age $\left(x_{1}\right)$ & Age of the farmer in (years) & \pm \\
\hline Experience $\left(x_{2}\right)$ & Experience of the farmer in (years) & + \\
\hline Education $\left(x_{3}\right)$ & Education of the farmer in (years) & + \\
\hline Household size $\left(x_{4}\right)$ & Number of the household of the farmer (Number) & \pm \\
\hline Off-farm income $\left(x_{5}\right)$ & 1 if the farmer has off-farm income; 0 otherwise & \pm \\
\hline Membership $\left(x_{6}\right)$ & $\begin{array}{l}1 \text { if the farmer has an association with any agricultural } \\
\text { organization; } 0 \text { otherwise }\end{array}$ & + \\
\hline Cell phone $\left(x_{7}\right)$ & 1 if the farmer use cell phone; 0 otherwise & + \\
\hline \multicolumn{3}{|c|}{--------------------------------------------------------------Farm resources factors---------------------------------------------------- } \\
\hline Livestock ownership $\left(x_{8}\right)$ & 1 if the farmer own livestock; 0 otherwise & + \\
\hline Machinery ownership $\left(x_{9}\right)$ & $\begin{array}{c}\text { If the farmer owns any machinery (e.g., tractor, sprayer, and } \\
\text { harvesting kit); } 0 \text { otherwise }\end{array}$ & + \\
\hline Farm size $\left(x_{10}\right)$ & Peach farm size in (acre) & + \\
\hline \multicolumn{3}{|c|}{ 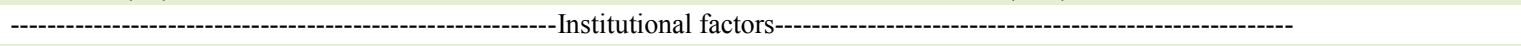 } \\
\hline Access to credit $\left(x_{11}\right)$ & 1 if the farmer has access to credit; 0 otherwise & + \\
\hline Extension services $\left(x_{12}\right)$ & 1 if the farmer has access to extension services; 0 otherwise & + \\
\hline Role of NGOs $\left(x_{13}\right)$ & 1 if the farmer has access to NGOs; 0 otherwise & + \\
\hline Inputs price $\left(x_{14}\right)$ & low $=1$, medium $=2$, high $=3$ & + \\
\hline \multicolumn{3}{|c|}{ 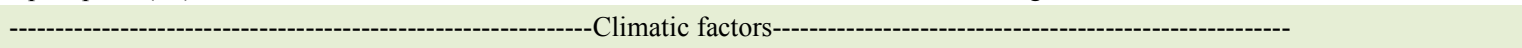 } \\
\hline Natural disasters risk perception $\left(x_{15}\right)$ & low $=1$, medium $=2$, high $=3$ & + \\
\hline Soil quality perception $\left(x_{16}\right)$ & low $=1$, medium $=2$, high $=3$ & + \\
\hline Weather shocks awareness $\left(x_{17}\right)$ & low $=1$, medium $=2$, high $=3$ & + \\
\hline
\end{tabular}

GRAZHDANI (2013), and Adesina \& Baidu-Forson (1995). Moreover, PAUDEL et al. (2008) argued that young farmer comparatively would be in favour of new technology. In contrast, older farmers are conservative to adopt new technology. This statement is endorsed by ABDOULAYE \& SANDERS (2005), ABDULAI \& HUFFMAN (2014) and EMMANUEL et al. (2016) in their respective studies. Education plays an important role in judging the behaviours and attitude of the farmers (AYDOGDU \& YENIGÜN, 2016) and creates opportunities to improve the managerial ability of farmers (NYUOR et al., 2016). In this study education of the farmer had a positive effect on ICs adoption. It is interesting that with the increase in years of schooling the probability of adopting ICs would be enhanced by $0.4 \%$. This result reveals that technology adoption rate increases if farmers are more educated (MARIANO et al., 2012). Household size had a positive relationship with the adoption of ICs. This result also strengthens our initial hypothesis. The positive sign indicates that with increasing size of the household, the probability of farmers' adoption of ICs increases. The reason is large family size can provide more labor during the production process and reduce the pressure of paying wages to extra labor. Cell phone usage of the farmer exerts a positive influence on the adoption of ICs. This finding is in agreement with the general belief that the use of cell phone increases extension agent contact and increases farmers' production capacity. Accordingly, those farmers who use the cell phone frequently, receive more information and probability of adopting new technology increases (BOLARINWA \& OYEYINKA, 2011). Estimated marginal effects suggested that the probability of adopting the ICs increases by $4 \%$ with the increase in usage of cell phone.

Farm resources had significant influences on the adoption of ICs technology except for farm size. However, the estimated coefficient of farm size had a positive impact on ICs. Farm size determines the intensity of resources used by farmers. This result implies that farmers who cultivate large orchards have a higher probability of adopting ICs. Apparently, such farmers are business oriented and sell fruits in the market. Therefore, to obtain higher productivity, they tend to create new ways to maximize their profit by adopting ICs technology. Conversely, the fact that 
Table 2 - Descriptive statistics of explanatory variables for adopters and non-adopters of ICs technology.

\begin{tabular}{|c|c|c|c|c|c|c|}
\hline \multirow[t]{2}{*}{ Variables } & \multicolumn{2}{|c|}{----------Adopters--------- } & \multicolumn{2}{|c|}{-------Non-Adopters------ } & \multicolumn{2}{|c|}{------All Respondents----- } \\
\hline & Mean & Std. Dev. & Mean & Std. Dev. & Mean & Std. Dev. \\
\hline Number of Farmers & \multicolumn{2}{|c|}{------------N=93--------- } & \multicolumn{2}{|c|}{----------N=177-------- } & \multicolumn{2}{|c|}{--N=270--- } \\
\hline $\operatorname{Age}\left(\mathrm{x}_{1}\right)$ & 42.688 & 11.904 & 41.927 & 10.996 & 42.189 & 11.301 \\
\hline Experience $\left(\mathrm{x}_{2}\right)$ & 8.871 & 7.580 & 7.559 & 6.245 & 8.011 & 6.750 \\
\hline Education $\left(\mathrm{x}_{3}\right)$ & 6.323 & 5.263 & 4.531 & 4.828 & 5.148 & 5.045 \\
\hline Household size $\left(\mathrm{x}_{4}\right)$ & 6.591 & 1.979 & 6.531 & 1.859 & 6.552 & 1.898 \\
\hline Off-farm income $\left(\mathrm{x}_{5}\right)$ & 0.505 & 0.503 & 0.367 & 0.483 & 0.415 & 0.494 \\
\hline Membership $\left(\mathrm{x}_{6}\right)$ & 0.366 & 0.484 & 0.249 & 0.433 & 0.289 & 0.454 \\
\hline Cell phone $\left(\mathrm{x}_{7}\right)$ & 0.785 & 0.413 & 0.661 & 0.475 & 0.704 & 0.457 \\
\hline Livestock ownership $\left(\mathrm{x}_{8}\right)$ & 0.538 & 0.501 & 0.333 & 0.473 & 0.404 & 0.492 \\
\hline Machinery ownership ( $\left.\mathrm{x}_{9}\right)$ & 0.323 & 0.470 & 0.164 & 0.371 & 0.219 & 0.414 \\
\hline Farm size $\left(\mathrm{x}_{10}\right)$ & 0.323 & 0.470 & 3.134 & 1.153 & 3.266 & 1.197 \\
\hline Access to credit $\left(\mathrm{x}_{11}\right)$ & 3.517 & 1.244 & 0.412 & 0.494 & 0.489 & 0.501 \\
\hline Extension services $\left(\mathrm{x}_{12}\right)$ & 0.634 & 0.484 & 0.333 & 0.473 & 0.389 & 0.488 \\
\hline NGOs $\left(\mathrm{x}_{13}\right)$ & 0.495 & 0.503 & 0.271 & 0.446 & 0.281 & 0.451 \\
\hline Inputs price $\left(\mathrm{x}_{14}\right)$ & 0.301 & 0.461 & 1.638 & 0.849 & 1.837 & 0.910 \\
\hline Natural disasters risk perception $\left(\mathrm{x}_{15}\right)$ & 2.215 & 0.907 & 2.232 & 0.844 & 2.378 & 0.808 \\
\hline Soil quality perception $\left(\mathrm{x}_{16}\right)$ & 2.656 & 0.651 & 2.175 & 0.760 & 2.344 & 0.769 \\
\hline Weather shocksawareness $\left(\mathrm{x}_{17}\right)$ & 2.667 & 0.681 & 1.531 & 0.791 & 1.833 & 0.916 \\
\hline
\end{tabular}

Source: Field survey, 2015.

farmers who cultivate small orchards are highly riskaverse concerning new technology due to the limited size and uncertain outcomes from the technology. This finding is consistent with the previous study of GRAZHDANI (2013). Livestock ownership is positively correlated with the adoption of peach ICs technology. Livestock number is an important economic factor that can not only determine ability to adopt technology but also can affect the kind of technology choice (mainly organic versus inorganic). The use of organic fertilizer is a major component of a sustainable agricultural system and a commonly suggested method of improving soil fertility while capturing economies of scope in crop-livestock systems (ASFAW et al., 2016). In addition, livestock contributes to ICs technology within the cropping system in various ways but directly through dung used as farmyard manure. Farmers with livestock could thus apply farmyard manure with inorganic fertilizer and residue incorporation. The coefficient of machinery ownership confirmed the positive and significant effect on ICs adoption. The estimated marginal effect shows that the probability of adopting the technology increases by $10.1 \%$ if a farmer has own farm machinery in use. The productivity of the technology increases when complemented with mechanization and naturally ICs are adopted for higher production.

The next set of explanatory variables is composed of institutional determinants such as access to credit, extension services, NGOs, and input price. The estimated coefficients of the investigated variables confirm to a priori expectations about their influence on the adoption of technology. The effect of credit was significant at $10 \%$ level of significance, and the estimated marginal effects suggested that the availability of credit increases the likelihood of ICs adoption by $8.2 \%$. The use of ICs requires more expenditure than local cultivar due to their higher price. In addition, they also require more inputs of fertilizer and pesticide to boost their production. Hence, as most farmers have not enough money to buy all inputs to spend at a time on all production operation of peach. Therefore, with the availability of necessary credit, farmers are able to purchase productive farm inputs and invest in the technology. Our result coincided with the finding of ABDULAI et al. (2011). Fluctuations in prices in agricultural crops combined with the continuity of high production input prices resulted in many changes in the agriculture sector 
Table 3 - Estimated coefficients and marginal effects of the logit model.

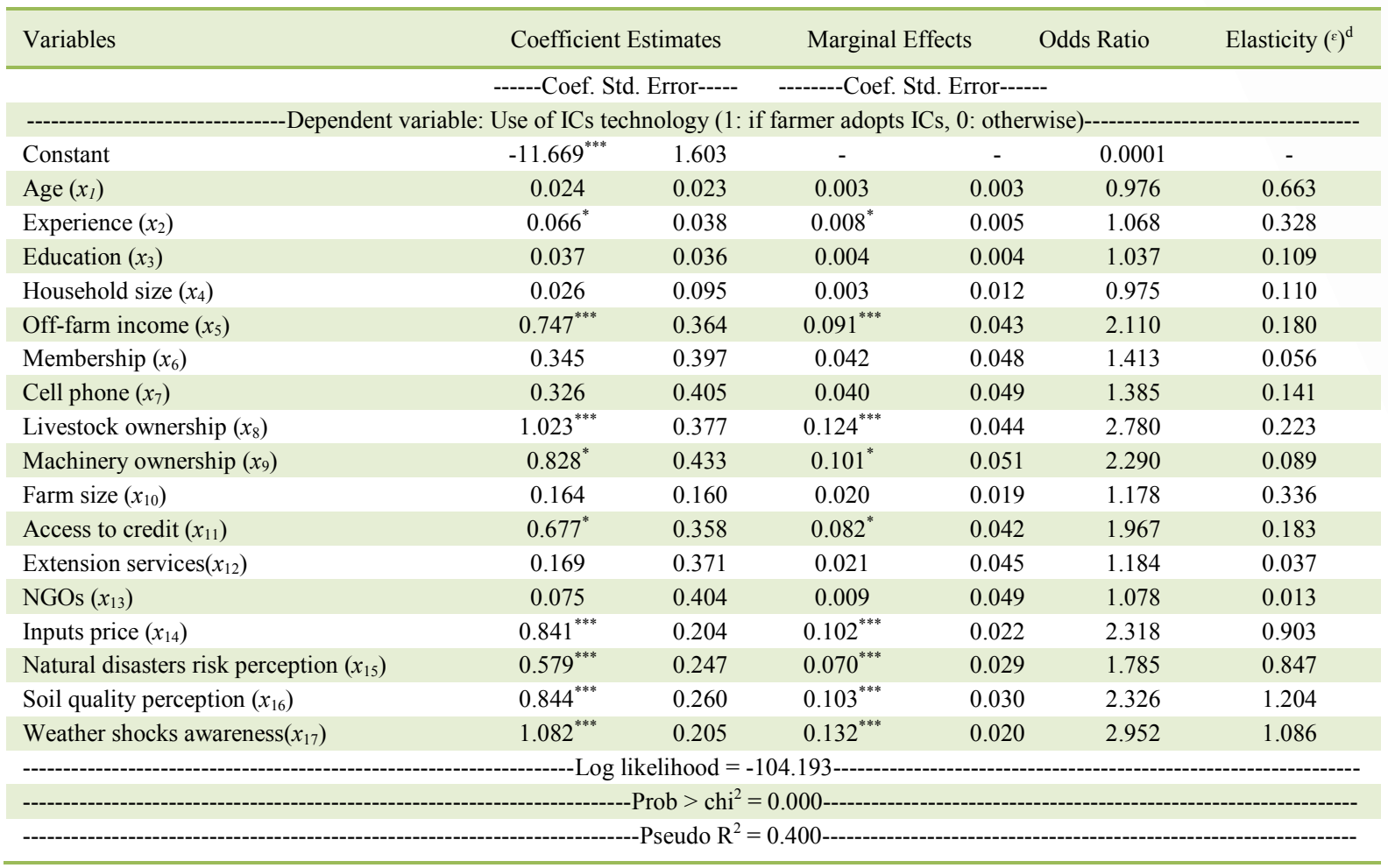

Note: Asterisks indicate significance at ${ }^{*} 10 \%,{ }^{* *} 5 \%$ and ${ }^{* * *} 1 \%$.

Source: Field survey, 2015.

such as farmers' confusion and unclear decision making regarding the allocation of areas to be cultivated with various crops. Here in our case, we reported that inputs price had a positive relationship with the adoption of ICs. When the inputs price is increasing, the adoption of ICs increases. Peach production is heavily dependent on inputs, such as fertilizers, pesticides, and other nutrients. If the price of these inputs is high in the market, then the farmer gives priority to adopt ICs for higher production. The access to extension services was found to be an appropriate factor encouraging the adoption of technology. Ali \& Rahut (2013) indicated that agricultural extension services play a significant role in the adoption of improved agricultural technologies. Extension agents are expected to provide farmers with useful information on production technologies, efficient input combinations and market information, all aimed at enhancing farm productivity and incomes (NYUOR et al., 2016). The results display those farmers who have adequate access to extension services have a higher probability of adopting ICs. The estimated marginal effects indicated that the availability of extension services increase the probability of ICs adoption by $2.1 \%$. The results confirm the usefulness of extension services in promoting agricultural technology in developing countries (ABDULAI \& HUFFMAN, 2014; EMMANUEL et al., 2016). The importance of NGOs role has been highly recognized by the farmer's perception of the adoption of modern technologies. There is a positive relationship between the role of NGOs and adoption of ICs of peach farmers. The estimated marginal effects indicated that the role of NGOs increases the probability of ICs adoption by $0.9 \%$. It means that NGOs are contributing to farmers in disseminating the information and knowledge about the adoption of modern technology.

The last sets of variables of our interest are climatic factors such as natural disasters risk perception, soil quality perception, and weather shocks awareness. The estimated coefficients of the investigated variables confirmed the positive sign and are highly significant at the $1 \%$ level of significance. 
Furthermore, the estimated marginal effects showed that appropriate information about climatic factors increases the probability of ICs by $7 \%, 10.3 \%$, and $13.2 \%$ respectively. These results suggested that farmers who have more information and knowledge about a climatic aspect of their farms are more likely to adopt ICs. These findings are consistent with TAMBO \& ABDOULAYE (2012) that farmers who are aware of the changing climate have a higher probability of adopting new technology. To minimize the impacts of climatic factors, horticulture scientists breed new peach cultivar which is more resilient to climatic condition and favorable to the production environment of farmers. It is crucial that horticulturist should find more scientific techniques such as a mutation in genes of peach varieties for improved resistance to biotic and abiotic stresses. These scientists need to increase their attention to breed varieties that have a higher tolerance to local abiotic stresses such as drought, flooding, and extreme temperatures as well as continuing to breed for resistance to pests and diseases. Priorities for breeding should consider the magnitude of the predicted impacts on productivity of the crop, the number of people who depend on the crop and their level of poverty, and the opportunities for significant gains through breeding. Local knowledge of ecological interactions, traditional varieties, and the genetic diversity in the farm crops provide abundant critical resources, to build priority breeding programs for climatic tolerant varieties.

\section{CONCLUSION}

The analyses developed in this research proves useful and providing evidence on an important issue concerning the adoption of ICs technology in peach production. Results obtained from the estimated model show robust support to most hypothesized effects and in agreement with previous empirical results in the literature or in accordance with the adopted theory. The significant factors that increase the adoption of ICs include farmer's experience, off-farm income, livestock and machinery ownership, access to credit, input price, natural disaster risk perception, soil quality perception and weather shock awareness.

Based on the results some fundamental policy implications can be drawn from this study. The role of institutional factors is critical in facilitating the adoption of practices that are risk reducing. Therefore, policymakers should promote research on the adoption of peach ICs technology for more production in the country. The government of Pakistan should take a proactive role to launch advance agricultural extension education program so that to guide the peach farmers in a better way. In conclusion, institutional services should be strengthened to provide managerial and technical skills on ICs technology adoption, and on time provision of financial services to enhance peach farmers productivity.

\section{ACKNOWLEDGMENTS}

This research was funded by Study on Effectiveness and Operational Mechanism Based on Self-Organizational Control of Regional Fruit Quality. Key Projects of Humanities and Social Science Research Supported by Northwest A\&F University of China (Grant No. Z109021414).

\section{DECLARATION \\ OF \\ CONFLICTING INTERESTS}

The authors declare no conflict of interest. The founding sponsors had no role in the design of the study; in the collection, analyses, or interpretation of data; in the writing of the manuscript, and in the decision to publish the results.

\section{AUTHORS' CONTRIBUTIONS}

$\mathrm{AU}$ and SZ conceived and designed the research. AU performed the data collection, analyzed the data and prepared the draft of the manuscript. AU, DK, SZ, and UA performed the proofread, edit, revised and approved the final version of manuscript collectively.

\section{REFERENCES}

ABDOULAYE, T.; SANDERS, J.H. Stages and determinants of fertiliser use in semiarid African agriculture: The Niger experience. Agricultural Economics, v. 32, n. 2, p. 167-179, 2005. Available from: <https://onlinelibrary.wiley.com>. Accessed: Apr. 22, 2018. doi: 10.1111/j.0169-5150.2005.00011.x.

ABDULAI, A.; HUFFMAN, W. The adoption and impact of soil and water conservation technology: an endogenous switching regression application. Land Economics, v.90, n.1, p.26-43, 2014. Available from: <http://le.uwpress.org>. Accessed: Apr. 22, 2018. doi: $10.3368 /$ le.90.1.26.

ABDULAI, A. et. al. Adoption of safer irrigation technologies and cropping patterns: evidence from southern Ghana. Ecological Economics, v.70, n.7, p.1415-1423, 2011. Available from: $<$ https://www.sciencedirect.com>. Accessed: Apr. 22, 2018. doi: 10.1016/j.ecolecon.2011.03.004

ABID, M. et. al. Farmers' perceptions of and adaptation strategies to climate change and their determinants: The case of Punjab province, Pakistan. Earth System Dynamics, v.6, n.1, p.225243, 2015. Available from: <https://www.earth-syst-dynam.net>. Accessed: Apr. 22, 2018. doi: 10.5194/esd-6-225-2015.

ADEBAYO, O.O. Determinants of extension service needs of catfish farmers in Oyo State, Nigeria (A case study of Ido local government area). IOSR Journal of Humanities and Social Science, v.1, n.4, p.54-58, 2012. Available from: <http://www.

Ciência Rural, v.48, n.11, 2018. 
iosrjournals.org/>. Accessed: Apr. 22, 2018.

ADESINA, A. A. ;BAIDU-FORSON, J. Farmers' perceptions and adoption of new agricultural technology: Evidence from analysis in Burkina Faso and Guinea, West Africa. Agricultural Economics, v.13, p.1-9, 1995. Available from: <https://www.sciencedirect.com>. Accessed: Apr. 22, 2018. doi: 10.1016/0169-5150(95)01142-8.

AHMED, M.N.; SCHMITZ, M. Economic assessment of the impact of climate change on the agriculture of Pakistan. Business and Economic Horizon, v.4, p.1-12, 2011. Available from:<https://www.pieb.cz>. Accessed: Apr. 22, 2018.

AKUDUGU, M.A. et. al. Adoption of modern agricultural production technologies by farm households in Ghana: What factors influence their decisions. Journal of Biology, Agriculture and Healthcare, v.2, n.3, 2012. Available from: <https://www. iiste.org>. Accessed: Apr. 22, 2018

ALI, A.; RAHUT, D.B. Impact of agricultural extension services on technology adoption and crops yield: Empirical evidence from Pakistan. Asian Journal of Agriculture and Rural Development, v.3, p.801-812, 2013. Available from: <http://aessweb.com/ journal-detail.php?id=5005>. Accessed: Apr. 22, 2018.

ASFAW, S. et. al. Agricultural technology adoption under climate change in the Sahel : Micro-evidence from Niger. Journal of African Economies, p.1-33, 2016. Available from: <https://academic.oup. com>. Accessed: Apr. 22, 2018. doi: 10.1093/jae/ejw005.

AYDOGDU, M.; YENIGÜN, K. Farmers' risk perception towards climate change: a case of the gap-şanliurfa region, Turkey. Sustainability, n.8, p.806, 2016. Available from: <http://www. mdpi.com>. Accessed: Apr. 22, 2018. doi: 10.3390/su8080806.

BAKHSH, K. et. al. Profitability and cost in growing mango orchards. Journal of Agriculture and Social Sciences, n.2, p.46-50, 2006. Available from: <http://www.fspublishers.org >. Accessed: Apr. 22, 2018.

BOLARINWA, K.K.; OYEYINKA, R.A.Use of cell phone by farmers and its implication on farmers' production capacity in Oyo State Nigeria. International Journal of Biological, Food, Veterinary and Agricultural Engineering, v.5, n.3, p. 9-14, 2011 Available from: <https://scholar.waset.org/1307-6892/11792>. Accessed: Apr. 22, 2018.

CHAVAS, J. et. al.Farm household production efficiency: Evidence from the Gambia. American Journal of Agricultural Economics, v.87, n.1, p.160-179, 2016. Available from: <https:// www.jstor.org>. Accessed: Apr. 22, 2018.

DIAO, X. et. al. The role of agriculture in African development World Development, v.38, n.10, p.1375-1383, 2010. Available from: <https://www.journals.elsevier.com/world-development> Apr. 22, 2018. doi: 10.1016/j.worlddev.2009.06.011.

EMMANUEL, D. et. al. Impact of agricultural extension service on adoption of chemical fertiliser: Implications for rice productivity and development in Ghana. NJAS - Wageningen Journal of Life Sciences, v.79, p.41-49, 2016. Available from: <https://www. sciencedirect.com>. Accessed: Apr. 22, 2018. doi: 10.1016/j. njas.2016.10.002.

GOP. Government of Pakistan. Economic survey of Pakistan 2014-2015. Finance Division. Economic Adviser's Wing, Islamabad, 2015. Available from: <http://www.finance.gov.pk/>.
Accessed: Jul. 22, 2018

GOP. Government of Pakistan. Fruit, vegetables and condiments statistics of Pakistan 2014-2015. Ministry of National Food Security \& research Economic Wing, Islamabad, 2015. Available from: <http://www.amis.pk>. Accessed: Jul. 22, 2018.

GOP. Government of Pakistan. Economic survey of Pakistan 2016-2017. Finance Division. Economic Adviser's Wing, Islamabad, 2017. Available from: <http://www.finance.gov.pk/>. Accessed: Jul. 22, 2018.

GRAZHDANI, D. An analysis of factors affecting the adoption of resource-conserving agricultural technologies in Al-Prespa park. Natura Montenegrina, Podgorica, v.2, n.12, p.431-444, 2013. Available from: <http://www.pmcg.co.me>. Accessed: Apr. 22, 2018.

GREENE, W.H. Econometric Analysis of Count Data, $5^{\text {th }}$ Edition. Pearson education, Inc., New Jersey. (2005). Available from: $<$ https://spu.fem.uniag.sk $>$. Accessed: Apr. 22, 2018.

HABIB, S. Peach: Queen of fruits. Pakistan Food Journal, p. 2627, September-October-2015. Available from: <http://foodjournal. pk>. Accessed: Nov. 19, 2017.

HENSHER, D.; JOHNSON, L. Applied Discrete Choice Modeling. London: Croom Helm. (1981). Available from: <https:// books.google.co.in>. Accessed: Apr. 22, 2018.

HILL, R.C. et. al. Principles of econometrics, $3^{\text {rd }}$ Edition. Wiley New York. 2008. Available from: <https://www.amazon.com>. Accessed: Apr. 22, 2018.

KHAN, M.A.A. et. al. National Economic \& Environmental Development Study (NEEDS). Government of Pakistan, Ministry of Environment. 2011. Available from: <https:// unfccc.int/files/adaptation/application/pdf/pakistanneeds.pdf $>$. Accessed: Apr. 22, 2018.

KHAN, M.A. Agricultural development in Khyber Pakhtunkhwa, prospects, challenges and Policy options. Pakistaniaat: A Journal of Pakistan Studies, v.4, n.1, p.49-68, 2012. Available from: $<$ http://citeseerx.ist.psu.edu $>$. Accessed: Apr. 22, 2018. doi: 10.1.1.888.7803.

MARIANO, M.J. et. al. Factors influencing farmers' adoption of modern rice technologies and good management practices in the Philippines. Agricultural Systems, 110, 41-53. 2012. Available from: <https://www.sciencedirect.com>. Accessed: Apr. 22, 2018. doi: 10.1016/j.agsy.2012.03.010.

MARTIN, K.L. et. al. Plant-to-plant Variability in Corn Production. Agronomy Journal, n. 97, p. 1603-1611, 2005. Available from: $<$ https://dl.sciencesocieties.org>. Accessed: Apr. 22, 2018. doi: 10.2134/agronj2005.0129.

MARTEY, E. et. al. Fertiliser adoption and use intensity among smallholder farmers in northern Ghana: a case study of the Agra soil health project. Sustainable Agriculture Research, v.3, n.1, p. 24-36, 2014. Available from: <http://dx.doi.org/10.5539/sar. v3n1p24>. Accessed: Apr. 22, 2018. doi: 10.5539/sar.v3n1p24.

MUTENJE, M. et. al. Agricultural innovations and food security in Malawi: Gender dynamics, institutions and market implications. Technological Forecasting and Social Change, v.103, p. 240 248, 2016. Available from: <https://www.sciencedirect.com>. 
Accessed: Apr. 22, 2018. doi: 10.1016/j.techfore.2015.10.004. NAMBIRO, E. et. al. Decentralization and access to agricultural extension services in Kenya: In International Association of Agricultural Economists, 2006 Annual Meeting p. 12-18. 2006. Available from: <http://ageconsearch.umn.edu/bitstream/25246/1/ pp060168.pdf>. Accessed: Apr. 22, 2018.

NYUOR, A.B. et. al. Economic impacts of climate change on cereal production: Implications for sustainable agriculture in northern Ghana. Sustainability, v.8, n.8, p. 724, 2016. Available from: <http://www.mdpi.com>. Accessed: Apr. 22, 2018. doi: $10.3390 /$ su8080724.

OSENI, G.; WINTERS, P. Rural nonfarm activities and agricultural crop production in Nigeria. Agricultural Economics, v.40, n.2, p. 189-201, 2009. Available from: <https://onlinelibrary.wiley.com $>$. Accessed: Apr. 22, 2018. doi: 10.1111/j.1574-0862.2009.00369.x.

PAN, D. The impact of agricultural extension on farmer nutrient management behaviour in Chinese rice production: A householdlevel analysis. Sustainability, v.6, n.10, p. 6644-6665, 2014 Available from: <http://www.mdpi.com>. Accessed: Apr. 22, 2018. doi: 10.3390/su6106644.

PAUDEL, K. et. al. Factors influencing and steps leading to the adoption of best management practices by Louisiana dairy farmers. Journal of Agricultural and Applied Economics, v.40 n.1, p.203-222, 2008. Available from: $<$ https://ageconsearch.umn.edu/ bitstream/45519/2/jaae-40-01-203.pdf>. Accessed: Apr. 22, 2018.

$\mathrm{SHAH}, \mathrm{M}$. et. al. Morphological study of different stone fruit species budded on peach rootstock under agro-climatic conditions of Mansehra, Pakistan. Sarhad Journal of Agriculture, v.29, n.4, p. 543-546, 2013. Available from: <https://www.aup.edu.pk/sj>.
Accessed: Apr. 22, 2018.

SMITH, J.B.Technologies to support climate change adaptation in developing Asia, Asian Development. Bank Mandaluyong City, Philippines. 2014. Available from: $<$ https://www.adb.org $>$. Accessed: Apr. 22, 2018.

TAMBO, J.A.; ABDOULAYE, T. Climate change and agricultural technology adoption : the case of drought-tolerant maize in rural Nigeria. Mitigation And Adaptation Strategies For Global Change, v.17, n.3, p.277-292, 2012. Available from: $<$ https://link. springer.com>. Accessed: Apr. 22, 2018. doi: 10.1007\%2Fs11027011-9325-7.

TOKATLIDIS, I.S. Crop adaptation to density to optimize grain yield: Breeding implications. Euphytica, n. 213, p. 92, 2017. Available from: < https://link.springer.com>. Accessed: Apr. 22, 2018.

UNIDO. Report on enterprise-based survey of horticulture sector. Retrieved from trade-related technical assistance programme Pakistan, 2010. Available from: <http://trtapakistan. org/wp-content/uploads/2011/01/Sector-Report-Horticulture.pdf $>$. Accessed: Apr. 22, 2018.

World Bank.World Development Report 2010: Development and Climate Change. The International Bank for Reconstruction and Development/The World Bank, Washington, DC. 2009. Available from: <https://siteresources.worldbank. org/INTWDR2010/Resources/5287678-1226014527953/ WDR10-Full-Text.pdf>. Accessed: Apr. 22, 2018.

YU, F. et. al. Proteomic analysis of postharvest peach fruit subjected to chilling stress or non-chilling stress temperatures during storage. Scientia Horticulturae, 197, 72-89. 2015. Available from: $<$ http:// www.sciencedirect.com/science/article/pii/S0304423815302739>.

Ciência Rural, v.48, n.11, 2018. 